\title{
Bloat and colic in horses experimentally induced by the ingestion of Panicum maximum cv. 'Mombaça'
}

\author{
Timpanismo e cólica em equinos induzidos experimentalmente pela ingestão de Panicum maximum \\ cv. 'Mombaça'
}

\section{Valíria Duarte Cerqueira ${ }^{\mathrm{I}}$ Gabriela Riet-Correa ${ }^{\mathrm{I}}$ Marcos Dutra Duarte $^{\mathrm{I}}$ Carlos Alberto de Oliveira $^{\mathrm{II}}$ Franklin Riet-CorreaII}

\begin{abstract}
In the Amazon region, sprouting pastures of Panicum maximum cause colic and death in horses and mules. To produce the disease two experiments were performed with growing P. maximum cv. 'Mombaça' in penned horses. In Experiment 1, at the beginning of the raining season, 10 horses were fed with recently harvested sprouting $P$. maximum. Two horses showed colic on the $5^{\text {th }}$ and $11^{\text {th }}$ day after start of the ingestion. In Experiment 2, also during the raining season, the same 10 horses used in Experiment 2 were divided into two groups of 5 horses each. Group 1 received sprouting $\boldsymbol{P}$. maximum immediately after harvested and Group 2 received the grass 24 hours after harvested. The control group consisted of four animals which were placed in individual pens and fed with Pennisetum purpureum and commercial ration twice a day. One horse from Group 2 showed colic on day $13^{\text {th }}$ after the start of feeding. The other horses of both groups showed intestinal bloat. In both experiments affected horses recovered after the end of the administration. The control group did not showed clinical signs. These results demonstrated that the disease is caused by the ingestion of sprouting P. maximum during the rainy season. The results in experiment 2 showed that $\boldsymbol{P}$. maximum do not loss toxicity 24 hours after harvesting. Clinical signs suggest that primary alteration caused by $\boldsymbol{P}$. maximum is intestinal fermentation followed by bloat.
\end{abstract}

Key words: acute abdomen, equidae, intestinal disorders, Panicum maximum.

\section{RESUMO}

Na região Amazônica, Panicum maximum em brotação causa cólica em equinos durante o período chuvoso. Com o objetivo de reproduzir experimentalmente a doença, foram realizados dois experimentos com $P$. maximum $\mathrm{cv}$.

\begin{abstract}
'Mombaça' em brotação. No Experimento 1, 10 equinos receberam o capim em brotação, ofertado no coxo. Dois animais apresentaram cólica, um no $5^{\circ}$ dia e outro no $11^{\circ}$ dia de experimento. No Experimento 2, também durante a época de chuvas, os mesmos 10 animais foram separados em dois grupos de 5, um grupo recebia $\boldsymbol{P}$. maximum recém cortado $e$ o outro recebia o capim cortado e dessecado à sombra durante 24 horas antes da administração. O grupo controle de ambos os experimentos foi constituído por quatro equinos, mantidos em baias individuais, recebendo capim Pennisetum purpureum picado e ração comercial duas vezes ao dia. No grupo que recebia o capim coletado com 24 horas de antecedência, um animal apresentou cólica no $13^{\circ}$ dia de experimento. Os demais equinos dos grupos 1 e 2 mostraram sinais de timpanismo intestinal. Nos dois experimentos, os animais afetados recuperaram-se espontaneamente após o final da ingestão. $O$ grupo controle não apresentou sinais clínicos. Os resultados comprovam que a doença é causada pela ingestão de pastagens de $\boldsymbol{P}$. maximum em brotação. Os resultados do Experimento 2 demonstraram que $\boldsymbol{P}$. maximum não perde toxicidade 24 horas após a coleta. Os sinais clínicos observados sugerem que a alteração primária causada por $\boldsymbol{P}$. maximum é uma alteração fermentativa com produção de gás e timpanismo intestinal.
\end{abstract}

Palavras-chave: abdomen agudo, doenças intestinais, equídeos, Panicum maximum.

An acute illness characterized by bloat and colic was recently reported in horses and mules grazing during the rainy season (November-May) in pastures of Panicum maximum cultivars (cv.) 'Mombaça', Tanzania and Massai in the Amazon region, in the states of Pará, Tocantins, Acre, and Rondonia (CERQUEIRA

\footnotetext{
IFaculdade de Veterinária, Universidade Federal do Pará (UFPA), BR 316, Km 62, 68740-970, Castanhal, PA, Brasil. E-mail: griet@ufpa.br. *Autor para correspondência.
}

IICentro de Saúde e Tecnologia Rural (CSTR), Hospital Veterinário, Universidade Federal de Campina Grande (UFCG), Patos, PB, Brasil. 
et al., 2009). The cause of colics associated with $\boldsymbol{P}$. maximum is unknown, but a previous research ruled out the possibility that the disease is caused by oxalates or saponins contained in the pasture or by contamination by Pithomyces chartarum or insects of the genus Epicauta producers of cantharidin (CERQUEIRA et al., 2009). The objectives of these experiments were to reproduce the colic by the ingestion of sprouting pastures of $\boldsymbol{P}$. maximum administered immediately after harvesting and 24 hours after.

Experiment 1: This experiment was started 14 days after the beginning of the rainy season (February). Ten crossbred horses, male and females, aged 1-3 years, and weighing about $200 \mathrm{~kg}$ were purchased from the region of Tracuateua, state of Pará, Brazil, where there are only native pastures. The animals were transferred to a farm located in the municipality of Castanhal, on the same state, and kept in covered individual boxes. Before the experiment they were adapted during one week receiving water and Pennisetum purpureum cv. 'Napier' ad libitum, examined clinically, and treated for gastrointestinal parasites. After the adaptation period the animals received water ad libitum and $\boldsymbol{P}$. maximum $\mathrm{cv}$. 'Mombaça' in a dry matter amount equivalent to 3\% of their body weight. Before starting the experiment cattle were introduced in the paddock and after intensive grazing they were removed leaving the pasture without grazing for 15 days. The grass was collected by cutting the pasture and offered twice daily, during morning and evening. The horses were inspected daily and examined once a week, checking the heart and respiratory rates, mucous membrane color, bowel movements, capillary refill time, and body temperature. Before the start of the experiment and weekly during the experiment, blood samples were collected with and without anticoagulant (EDTA) for hemogram and determination of serum concentrations of urea and creatinine, and serum activities of aspartate aminotransferase (AST) and gamma glutamyl transferase (GGT). Hemograms were performed using a hematological autoanalyzer vet 2800 BC, apparatus MINDRAY. Serum concentrations of urea and creatinine were determined by colorimetric methods using the Bioplus apparatus. The measurements of AST and GGT were analyzed using autoanalyzer apparatus Selecta E. After observing the first signs of colic, the administration of $\boldsymbol{P}$. maximum was ended. The affected animals were fasted until the disappearance of clinical signs, and were later fed $\boldsymbol{P}$. purpureum cv. 'Napier'. The experiment lasted 15 days.

Experiment 2: This experiment was conducted during March, with the same 10 horses and the same pasture of $\boldsymbol{P}$. maximum cv. 'Mombaça' used in Experiment 1. Since the start of Experiment 1, the pasture was divided into areas in a way that the $\boldsymbol{P}$. Maximum collected daily had 15 to 30 days of sprouting. After 10 days of the end of Experiment 1, the same 10 animals, which had been grazing in a paddock of $\boldsymbol{P}$. purpureum cv. 'Napier', were divided into two groups of five animals each. One group received sprouting $\boldsymbol{P}$. maximum cv. 'Mombaça' immediately after harvesting, and the other group received $\boldsymbol{P}$. maximum cv. 'Mombaça' collected in the same pasture, but partially dried in the shade for 24 hours before administration. These groups were divided at random, but with the presence of one of the animals affected in the previous experiment in each group. The grass collected 24 hours before the administration was weighed after collection and before administration to maintain a dry matter ingestion equivalent to $3 \%$ body weight. In both groups, the grass was fed twice daily and all animals received water ad libitum. Clinical examination and blood sampling was performed in similar way than in Experiment 1. After observing the first signs of colic, the administration of $\boldsymbol{P}$. maximum was ended. The affected animals were fasted until the disappearance of clinical signs, and were later fed $\boldsymbol{P}$. purpureum cv. 'Napier'. The experiment lasted 22 days. The control group for the both experiments consisted of four animals which were placed in individual pens and fed with Pennisetum purpureum and commercial ration twice a day.

In Experiment 1, that began 14 days after the start of the raining period and lasted 14 days, two animals had diarrhea and flatulence on the $3^{\text {rd }}$ day (Horse 7) and $4^{\text {th }}$ day (Horse 9) after the start of $\boldsymbol{P}$. maximum ingestion. After 5 days of experiment, Horse 1 showed colic during the morning. Also on day 5, all animals were with the abdomen distended with gas, but with no signs of colic. No changes in clinical pathology parameters were observed. Horse 4 presented colic on day 11. The two horses with colic showed bilaterally distended abdomen, and still lying and rolling on the floor of the bay. The capillary refill time ranged from 2 to 3 seconds. A hyperemic halo was observed around the teeth and the oral mucosa was dry. The horses opened the four limbs and stretched his body forward in the posture of urination. The heart rate in both animals at the time of the episode of colic, ranged from 38 to 40 beats per minute (BPM). Respiratory movements were around 28 per minute (MPM). After the first signs of colic, the two affected horses were removed from the experiment, being initially fasting with water ad libitum, and after improvement of clinical signs, received ground $\boldsymbol{P}$. purpureum cv. 'Napier'. The two affected horses did not require treatment and both recovered in about 6 hours after the end of $\boldsymbol{P}$. maximum ingestion. 
In Experiment 2, the five animals that received the grass recently collected showed no clinical manifestations of colic. Of the five animals that received grasses collected after 24 hours of harvesting, Horse 4 showed mild signs of colic on day 13 of the experiment. This animal, which also had been affected in Experiment 1 , was removed from the experiment and after 5 hours was recovered. The experiment lasted 22 days and all 10 animals from the two groups showed moderate distention of the abdomen. No changes in clinical pathology parameters were observed. The pastures administered 24 hours after harvesting loss about $20 \%$ of water. No clinical signs were observed in the control group.

During the two experiments the animals improved their body conditions.

The observation of colic and bloat in Experiments 1 and 2 demonstrated that the disease is caused by the ingestion of sprouting Panicum maximum during the raining season. In a previous experiment the diseases was not reproduced after the ingestion of newly growth $P$. maximum during the dry season (CERQUEIRA, 2010).

The abdominal distention caused by excessive gas production observed in all horses that received $\boldsymbol{P}$. maximum experimentally, even without colic, suggests that the primary change is fermentation followed by bloat. This is also suggested by the rapid regression of signs in the horses with colic after the removal of $\boldsymbol{P}$. maximum from the animal alimentation.

It has been suggested that colics caused by $\boldsymbol{P}$. maximum are due to high content of rapidly fermentable carbohydrates (soluble fiber, oligosaccharides, including some fructans and galactans, and starches resistant to hydrolysis) (CERQUEIRA, 2010). Nutritional analysis of $\boldsymbol{P}$. maximum pastures causing colic showed high concentrations of non-fibrous carbohydrates present during early growth (15-30 days) of $\boldsymbol{P}$. maximum and the decreased concentrations during maturation (4560 days) (CERQUEIRA, 2010), but specific analyses of rapidly fermentable carbohydrates were not performed. Research is necessary to determine the bromatologic composition of sprouting $\boldsymbol{P}$. maximum pastures and its relationship with equine colics. Recently, sprouting pastures of $\boldsymbol{P}$. maximum cv. 'Tanzania' had been associated with cecal dilatation and other digestive signs in cattle (RIET-CORREA et al., 2011).

In a previous experiment, 9 out of 10 horses showed severe colic after been introduced in a pasture of $\boldsymbol{P}$. maximum, whereas when the same pasture was cut during the afternoon and offered in the next morning, signs were lighter and only three out of five horses were affected (RIBEIRO, 2007 - verbal report), suggesting that $\boldsymbol{P}$. maximum pastures lost toxicity after being cut and dry. It has been also suggested that the high water content (nearly $80 \%$ ) of the pastures in budding do not meet the dry matter requirements for horses inducing the ingestion of large amounts of pastures that can induce colic (KING, 2000). Nevertheless, in Experiment 2, the observation of colic in one horse that receive $\boldsymbol{P}$. maximum 24 hours after harvesting and the presence of bloat in the other four horses suggest that $\boldsymbol{P}$. maximum do not lost toxicity 24 hours after harvesting. New experiments should be performed to determine a possible loss of toxicity after drying the pasture for more than 24 hours.

Cases of bloat in $\boldsymbol{P}$. maximum pastures (CERQUEIRA et al., 2009) showed clinical signs more severe than those observed experimentally in this research. This difference could be due to the fact that the horses eat larger amounts of grass during grazing, picking the young leaves (LONGLAND \& BYRD, 2006). Another factor that could be responsible for more severe cases on field conditions could be the lack of observation of the first clinical signs keeping the animals in the toxic pastures until the occurrence of severe clinical signs, and development of secondary lesions (bleeding, erosions and ulcerations of the digestive tract, and enteritis), which are probably secondary to intestinal bloat that is followed by decreased of motility, increased production of gas and lactic acid, muscle spasms, pain, and probably endotoxemia.

From the results obtained in these experiments and in previous reports is not possible to suggest definitive control measures to prevent colic caused by $\boldsymbol{P}$. maximum in horses and the only efficient way is to avoid grazing horses in P. maximum sprouting pastures during the rainy season.

\section{ACKNOWLEDGEMENTS}

This research was financially supported by the National Institute for Science and Technology for the Control of Poisoning Plants, grant Conselho Nacional de Desenvolvimento Científico e Tecnológico (CNPq) 573534/2008-0.

\section{BIOETHICS AND BIOSSECURITY COMMITTEE APPROVAL}

The protocol of this study in Ethics and Biosecurity Committee of the University of São Paulo is 1406/2008.

\section{VERBAL REPORT}

DJACY RIBEIRO, 2007. Universidade Federal Rural da Amazônia, Belém, Pará. E-mail: djacy.ribeiro@ufra.edu.br

\section{REFERENCES}

CERQUEIRA, V.D. et al. Colic caused by Panicum maximum toxicosis in equidae in northern Brazil. J Vet Diagn Invest, v.21, p.882-888, 2009. Available from: <http://vdi.sagepub.com/ content/21/6/882.full.pdf + html $>$. Accessed; Apr. 23, 2012. doi: $10.1177 / 104063870902100622$. 
CERQUEIRA, V.D. Cólica em equídeos mantidos em diferentes cultivares de Panicum maximum no bioma amazônico. 2010. 90f. Tese (Doutorado em Ciências) - Faculdade de Medicina Veterinária e Zootecnia, USP, São Paulo, SP.

KING, C. Preventing spring colic in horses: flying changes. 2000. Available from: <http://www.flyingchanges.com/htmls/ 2000/mar00colic.html> Accessed 8 jun. 2009.

LONGLAND, A.C.; BYRD, B.M. Pasture nonstructural carbohydrates and equine laminitis. Proceedings of the Waltham
International Nutritional Sciences Symposia. J Nutr, v.136, n.7S, p.2099S-2102S, 2006. Available from: <http:// jn.nutrition.org/content/136/7/2099S.full.pdf+html>. Accessed: 23 Apr. 2012.

RIET-CORREA B. et al. Alterações digestivas em bovinos mantidos em pastagem de $\boldsymbol{P}$. maximum cultivar 'Tanzânia'. Vet e Zootec v. 18, Supl.3, p.633-635, 2011. Available from: <www.fmvz.unesp.br/ revista/volumes/vol18/enfermidadestoxicas29.pdf $>$. Accessed: 23 Apr. 2012. 